\title{
Mode of referral to hospital of patients with heart attacks: relevance to home care and special ambulance services
}

\author{
J D HILL, J R HAMPTON
}

British Medical fournal, 1976, 2, 1035-1036

\section{Summary}

Out of 1250 consecutive patients brought to hospital with heart attacks $956(76 \%)$ were at home when their symptoms began. Of these, $587(61 \%)$ called their general practitioner, and for the remainder an ambulance was summoned by a member of the public. Of the 294 patients who were away from home when the attack occurred 291 were brought to hospital by ambulance. Of these, only 70 $(24 \%)$ were attended by a general practitioner. Patients for whom ambulances were called by a general practitioner had had their symptoms significantly longer and had significantly lower prehospital and hospital mortalities than those for whom ambulances were summoned by members of the public. Special "cardiac" ambulances appear to be inappropriate for patients who have been seen by a general practitioner, and for this group home care may well be as effective as hospital admission.

\section{Introduction}

Since most patients who die from a heart attack do so soon after the onset of symptoms, ${ }^{12}$ rapid remova' to hospital has been recommended, ${ }^{3}$ preferably in a "cardiac" ambulance. The only randomised trial so far reported of home versus hospital care for such patients, ${ }^{4}$ however, suggested that home care was at least as effective as hospital care in selected cases; and after a survey of patients with heart attacks seen by general practitioners Smyllie $e t a l^{5}$ suggested that because of the delay between the onset of symptoms and the call for an ambulance a special cardiac ambulance was unlikely to be useful for such patients. Furthermore, a single cardiac ambulance has no effect on mortality from heart attacks in an urban community, ${ }^{6}$ possibly partly because of the difficulty of identifying the patients it is most likely to help.

The apparent contradiction between the recommendations of the Joint Working Party ${ }^{3}$ and the results of previous studies may relate partly to the different circumstances in which heart attacks occur and the consequent different behaviour of the patient and other non-medical people. Here we emphasise the relevance to patient management of the place where a patient has his heart attack and of the first action that he or some other non-medical person takes.

\section{Methods}

We studied 1250 consecutive patients with heart attacks who were admitted to hospital in Nottingham. Of these, 282 arrived in a cardiac ambulance and three in a car; most were brought in by routine

Department of Medicine, General Hospital, Nottingham NG1 6HA J D HILL, MB, MRCP, lecturer in medicine

J R HAMPTON, DM, FRCP, consultant physician and reader ambulances. Data were collected daily from the ambulance service records, from the case notes in the accident and emergency department and wards, and, when appropriate, from coroner's and hospital necropsy records. When possible, supplementary data were obtained by direct questioning of the patient.

After the patient's discharge or death the records were assessed and the patient was allocated to one of the following categories of heart attack: (a) definite myocardial infarction-a convincing clinical story with unequivocal electrocardiogram (ECG) ( $Q$ wave and sequential S-T segment) and enzyme (serum hydroxybutyrate dehydrogenase) changes, or post-mortem evidence if the patient died after admission; (b) probable myocardial infarction-a convincing story with either unequivocal ECG or unequivocal enzyme changes; (c) possible myocardial infarction-a convincing story with an abnormal ECG that was not typical of a recent myocardial infarction and with a marginal rise in serum enzyme levels; $(d)$ ischaemic heart diseasepatients with convincing evidence of a previous infarction or angina and with an abnormal ECG but nothing to suggest a recent infarction; (e) chest pain of unknown cause-patients with normal ECGs and cardiac enzyme levels but in whom no other diagnosis was made; and $(f)$ prehospital death - patients who died before admission to hospital when a necropsy (usually for the coroner) showed either that death had been caused by a recent myocardial infarction or that it was attributable to coronary artery disease as no other abnormality was found.

\section{Results}

Altogether $956(76 \%)$ of the patients were at home when their heart attack occurred; of these, $587(61 \%)$ called their general practitioner, and for the remaining 369 the call for the ambulance was made directly by a relative or some other member of the public using an emergency 999 call. Of the 294 patients who were away from home when their heart attack occurred, 291 were brought to hospital by ambulance, a general practitioner having attended only $70(24 \%)$ of these. This difference between the two groups in the proportions attended by a general practitioner is statistically significant $(P<0 \cdot 001)$.

There were more men in the group whose attack occurred away from home; otherwise the patients in the groups for whom the ambulance was called by general practitioners or a member of the public and in the groups who had their attack at home or away from home were similar in age and sex distribution (table I); the proportions of those admitted to hospital and eventually diagnosed as having definite or probable myocardial infarctions were also similar.

The duration of symptoms before the ambulance call was known in more than $95 \%$ of cases, except in the group whose attack occurred at home and for whom the ambulance call was made by a member of the public; here the length of history was known in 319 of the 369 patients $(86 \%)$. Patients who called their general practitioner had had their symptoms longer than those for whom 999 calls were made by a mem-

TABLE I-Age, sex, and proportions of patients with definite or probable infarction*

\begin{tabular}{c|c|c|c|c}
\hline \multicolumn{1}{|c|}{$\begin{array}{c}\text { Ambulance } \\
\text { called by: }\end{array}$} & $\begin{array}{c}\text { Place of } \\
\text { heart attack }\end{array}$ & $\begin{array}{c}\text { Mean age } \\
\text { (years) }\end{array}$ & $\begin{array}{c}\% \\
\text { Men }\end{array}$ & $\begin{array}{c}\% \text { of patients } \\
\text { with definite } \\
\text { or probable } \\
\text { infarction }\end{array}$ \\
\hline $\begin{array}{c}\text { GP } \\
\text { (657 patients) }\end{array}$ & $\left\{\begin{array}{l}\text { At home } \\
(\mathrm{n}=587) \\
\text { Away from home } \\
(\mathrm{n}=70) \\
\text { At home } \\
(\mathrm{n}=369) \\
\text { (590 patients) } \\
(\mathrm{n}=221)\end{array}\right.$ & 56 & 89 & 77 \\
\hline
\end{tabular}

*Table excludes three patients brought to hospital by car. 


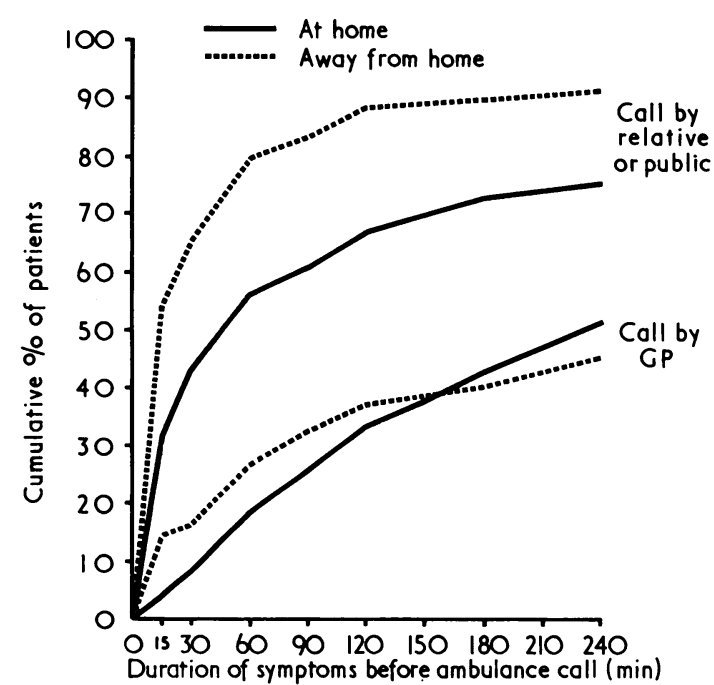

Duration of symptoms before ambulance call in different groups of patients.

ber of the public, whether the attack occurred at home or away from home (see figure).

A relative or member of the public called an ambulance within 30 minutes of the onset of symptoms in $138(43 \%)$ of the 319 patients whose attack occurred at home, and in $139(65 \%)$ of the 214 who were away from home $(P<0.001)$. A general practitioner called an ambulance within the same period for only $44(8 \%)$ of those patients at home and $11(16 \%)$ of those away from home.

The prehospital mortality was much lower among patients sent to hospital by a general practitioner ( $2 \%$ ) than among those for whom a 999 call had been made by a member of the public $(46 \%)$ (table II). This was true whether the patient was at home or away from home when the heart attack occurred. Moreover, among those patients reaching hospital alive the hospital mortality was also significantly $(P<0.05)$ lower in those patients for whom the ambulance was called by a general practitioner.

Attempts to establish the precise time of death of patients who were dead on arrival proved unsuccessful, as ambulance personnel are not allowed to pronounce a patient dead. All ambulance crews, however, are trained to resuscitate patients who have apparently died either in

TABLE II-Deaths among groups of patients with different modes of referral to hospital*

\begin{tabular}{c|c|c|c}
\hline $\begin{array}{c}\text { Ambulance } \\
\text { called by: }\end{array}$ & $\begin{array}{c}\text { Place of } \\
\text { heart attack }\end{array}$ & $\begin{array}{c}\text { No of } \\
\text { prehospital } \\
\text { deaths } \\
(\% \text { total })\end{array}$ & $\begin{array}{c}\text { No of } \\
\text { hospital deaths } \\
(\% \text { hospital } \\
\text { admissions })\end{array}$ \\
\hline $\begin{array}{c}\text { GP } \\
\text { (657 patients) }\end{array}$ & $\left\{\begin{array}{l}\text { At home } \\
\text { (n=587) } \\
\begin{array}{c}\text { Away from home } \\
(\mathrm{n}=70) \\
\text { (590 patients) }\end{array}\end{array}\right.$ & $2(2 \cdot 5)$ & $79(13 \cdot 7)$ \\
$\begin{array}{c}\text { At home } \\
(\mathrm{n}=369) \\
\text { Away from home } \\
(\mathrm{n}=221)\end{array}$ & $88(39 \cdot 8)$ & $63(8 \cdot 8)$ \\
\hline
\end{tabular}

*Table excludes three patients brought to hospital by car.

TABLE III-Numbers of patients on whom resuscitation was attempted by ambulance crews

\begin{tabular}{|c|c|c|c|}
\hline $\begin{array}{l}\text { Ambulance } \\
\text { called by: }\end{array}$ & $\begin{array}{c}\text { Place of } \\
\text { heart attack }\end{array}$ & \multicolumn{2}{|c|}{$\begin{array}{l}\text { No of attempted } \\
\text { resuscitat:ons }\end{array}$} \\
\hline $\begin{array}{c}\text { GP } \\
\text { (657 patients) }\end{array}$ & $\begin{array}{l}\text { At home } \\
(n=587) \\
\text { Away from home } \\
(n=70)\end{array}$ & $\begin{array}{r}11 \\
2\end{array}$ & $13(2 \cdot 0 \%)$ \\
\hline $\begin{array}{l}\text { Member of public } \\
\text { (590 patients) }\end{array}$ & $\begin{array}{l}\text { At home } \\
(n=369) \\
\text { Away from home } \\
(n=221)\end{array}$ & $\begin{array}{l}20 \\
29\end{array}$ & $49(8.3 \%)$ \\
\hline
\end{tabular}

their presence or shortly before their arrival, and all attempted resuscitations are recorded on the ambulance reports. The number of resuscitation attempts, therefore, probably represents the number of patients reached at a time when they might conceivably have been saved. Resuscitation was attempted on significantly $(P<0.001)$ more patients when the ambulance was summoned by a member of the public than when called by a general practitioner (table III).

The three patients brought to hospital by car all survived; they are not considered further.

\section{Discussion}

The patients in this study were identified through having been brought to hospital, and we did not attempt to determine the total number of patients with heart attacks in the community. We excluded patients treated at home, as well as any patient dying at home whose death was confirmed by a general practitioner and for whom a hearse was summoned rather than an ambulance; this must to some extent account for the low prehospital mortality among patients sent to hospital by a general practitioner.

We think our findings important for providing services for patients with heart attacks. If Nottingham is similar to the rest of the country, which it probably is, ${ }^{7}$ most heart attacks occur at home, and most patients summon their general practitioner rather than an ambulance. If a general practitioner is called at all the symptoms will probably have lasted for a long time, and the patient will already have survived the period of greatest:risk of a dangerous arrhythmia before receiving medical help. Furthermore, if such a patient is admitted to hospital the hospital mortality is relatively low and home care is likely to be as effective as hospital care. On the other hand, if an ambulance is summoned by a 999 call for a patient with a heart attack then the prehospital and hospital mortalities are likely to be high, and it is presumably this group of patients that a cardiac ambulance may possibly help.

Unfortunately it is by no means certain that such a special ambulance service will have any appreciable effect on mortality even in this limited group of patients, for in many cases the very reason for a 999 call is that the patient is already dead. Furthermore, it is extremely difficult for an ambulance controller to select from among the emergency calls made by members of the public those relating to patients with heart attacks: in Nottingham, at least, the commonest cause of a "collapse" is being drunk and incapable. ${ }^{8}$ Thus if a cardiac ambulance is to be sent to all emergency calls it will spend most of its time carrying drunks, and a single special vehicle will in any case be unable to handle all calls that might possibly be for patients with heart attacks.

The question of home or hospital care therefore remains open, but any study must take into account the mode of referral of the patient. The Nottingham cardiac ambulance is no longer available to general practitioners, and a randomised study of its use for emergency calls is in progress.

We gratefully acknowledge the help of Miss $\mathrm{C}$ Nicholas in collecting information, and the Department of Health and Social Security for a research grant.

\section{References}

${ }^{1}$ McNeilly, R H, and Pemberton, J, British Medical fournal, 1968, 3, 139. 2 Fulton, M, Julian, D G, and Oliver, M F, Circulation, suppl IV, 1969, 39 and 40.

${ }^{3}$ Joint Working Party of the Royal College of Physicians and the British Cardiac Society, Fournal of the Royal College of Physicians, 1975, 10, 5.

${ }^{4}$ Mather, H G, et al, British Medical Fournal, 1971, 3, 334.

5 Smyllie, H C, Taylor, M P, and Cunninghame-Green, R A, British Medical fournal, $1972,1,34$.

6 Hampton, J R, British Medical fournal, 1976, 1, 201.

7 Armstrong, A, et al, British Heart fournal, 1972, 34, 67.

${ }^{8}$ Cameron, M, Wilkinson, F, and Hampton, J R, British Medical fournal, 1975, 1, 384. 